\title{
The critical success factors of building smart green city logistics business in Fuzhou
}

\author{
Shih-Ming Oü ${ }^{\mathrm{a}}$, Qiaoping Mei, Li Yang and Dongling Chen \\ Department of Logistics Management, Fuzhou University of International Studies and Trade, Fujian, China
}

\begin{abstract}
This paper intends to find the critical success factors for smart green city logistics business in Fuzhou. We first investigate and collect the factors that impact the operations of smart green city logistics business. In order to acquire the experts' assessments on the influence between each two factors, we invite the managers who serve in the top five logistics companies in Fujian and conduct expect questionnaire investigation. By using DEMATEL method, we explore the causal effect among factors. Our findings show that the government investments and green power development are the two most influential factors among all.
\end{abstract}

\section{Introduction}

IBM proposed in 2009, to build a future-oriented concept of "smart logistics". Under this concept the supply chain is advanced, interconnected and intelligent. Through sensors, RFID tags, actuators, GPS as well as other devices and systems generate the general idea of "real-time intelligent supply chain". Smart logistics emphasizes on building a virtual logistics dynamic information management system.

With rapid rise of e-commerce, consumers' demands are stirred and largely increasing in the size of number of goods that results in highly development of logistics business. For sustainable development, green logistics concept has been spread worldwide. However, green technology and management still do not be adopted by most of the logistics companies in Fuzhou.

This study aims to explore the critical success factors for developing smart green city logistics business. To achieve the research objective, we first construct a hierarchy framework with the aspects of product, customer, operations management and finance as well as their rules. Then DEMATEL (Decision Making Trial and Evaluation Laboratory) method is employed to find the crucial factors.

The rest parts of this paper are organized as follows. Methodology that we employ in this paper is introduced in section two. In section three, we conduct an empirical study. The last part is the conclusion of this paper.

\section{Methodology}

DEMATEL (Decision Making Trial and Evaluation Laboratory) was first developed by A. Duval, E. Fontela and A. Gabus1 in 1970. It can be used to solve the world's complex problems, such as agriculture, race, environmental protection, trade, health care, etc.([1],[3],[4],[8],[9])

\footnotetext{
${ }^{\mathrm{a}}$ Corresponding author : benao13@gmail.com
} 
After establishing the aspects and rules that affect the system, acquiring the assessments from experts, as well, DEMATEL quantifies and compares the factors each other, and then clarifies the causal diagram.([2],[5]) Mathematically, the operational procedure can be presented as follows.[11] Step 1: Build hierarchy structure.

Step 2: Acquire experts' assessments.

Step 3: Construct initial direct-relation matrix.

$$
X=\left[\begin{array}{llll}
0 & x_{12} & \cdots & x_{1 n} \\
x_{21} & 0 & \cdots & x_{2 n} \\
\vdots & \vdots & \ddots & \vdots \\
x_{n 1} & x_{n 2} & \ldots & 0
\end{array}\right]
$$

where $x_{i j}, \mathrm{i}=1,2, \ldots, \mathrm{n} ; \mathrm{j}=1,2, \ldots, \mathrm{n}$, denote the influence of factor $\mathrm{i}$ to factor $\mathrm{j}$.

Step 4: Normalize direct-relation matrix

$$
\begin{aligned}
& S=\frac{1}{\operatorname{maX}_{1 \leq i \leq n} \sum_{j=1}^{n} a_{i j}} \\
& N=X \times S
\end{aligned}
$$

Step 5: Compute total relation matrix

$$
T=N(I-N)^{-1}
$$

\begin{tabular}{|c|c|c|}
\hline Aspect & Rule & Explanation \\
\hline Product & $\begin{array}{l}\text { Usage of green energy and } \\
\text { carbon reduction }\end{array}$ & $\begin{array}{l}\text { Pursuing environmental protection and energy } \\
\text { saving as well as carbon reduction as the main } \\
\text { value proposition. }\end{array}$ \\
\hline \multirow{3}{*}{ Consumer } & Environmentalist & $\begin{array}{l}\text { The customers who are willing to pay more for the } \\
\text { environmental sustainability. }\end{array}$ \\
\hline & Support from Government & $\begin{array}{l}\text { Assistance from government could improve the } \\
\text { operations of smart green city logistics business. }\end{array}$ \\
\hline & $\begin{array}{l}\text { Appling information } \\
\text { technology to logistics } \\
\text { business }\end{array}$ & $\begin{array}{l}\text { Appling information technology to logistics } \\
\text { business for more efficient customer relationships } \\
\text { maintaining. }\end{array}$ \\
\hline \multirow{3}{*}{$\begin{array}{l}\text { Operations } \\
\text { Management }\end{array}$} & Logistics service quality & Improvement of logistics service quality. \\
\hline & Infrastructure & R\&D platform and facility construction. \\
\hline & laws & $\begin{array}{l}\text { Legalization, standardization and } \\
\text { institutionalization of logistics industry. }\end{array}$ \\
\hline \multirow[b]{2}{*}{ Finance } & Logistics costs & Logistics cost control. \\
\hline & Company investments & $\begin{array}{l}\text { Expenditure on developing smart green logistics } \\
\text { business. }\end{array}$ \\
\hline
\end{tabular}

Step 6: Plot and analyze causal-effect diagram

\section{Empirical study}

Table 1. Aspects and rules. 
We conducted expert questionnaire during the period from September to December in 2015 to acquire the assessments of the managers who work in the major green logistics companies in Fuzhou. After rearranging data collected from experts, we have the aspects and rules as shown in Table 1.

We then processed the experts' assessments by using DEMATEL. The causal-effect diagram is presented as follows :

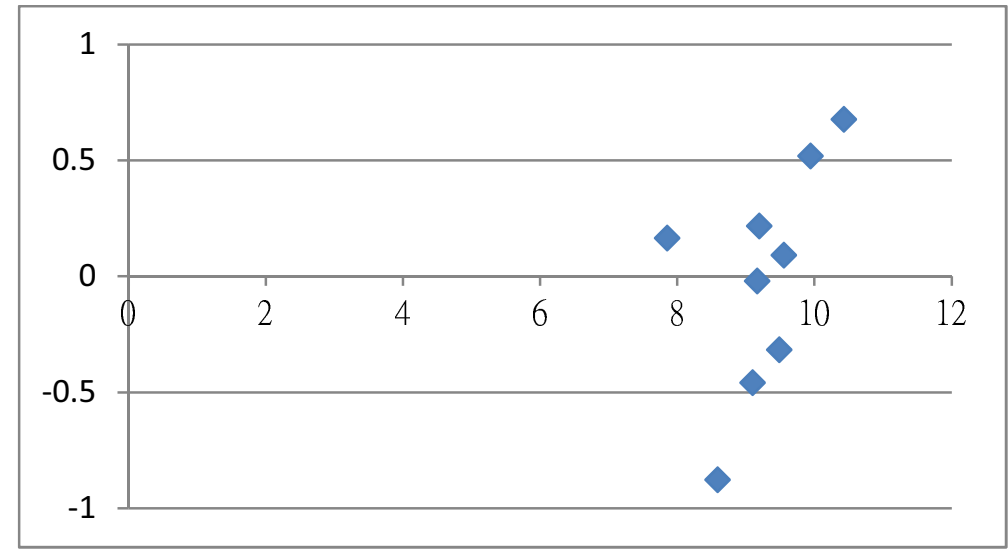

Figure 1. Causal-effect diagram.

Observing Figure 1 "Causal-effect diagram", the two factors of "Financial support from Government" and "Usage of green energy and carbon reduction" are crucial factors on developing smart green city logistics business.

\section{Conclusions}

In this study, we aim at finding the key success factors on developing smart green city logistics business. We acquire experts' assessments from main logistics companies in Fuzhou and then employ DEMATEL method to explore and visualize the causal relationships among factors. Our findings show that "Financial support from Government" and "Usage of green energy and carbon reduction" are the two key factors. That is, as long as the Government can give vigorously promote investment, it will facilitate the development of smart green city logistics business.

\section{References}

1. B. Chang, C.W. Chang, and C.H. Wu, Expert Syst Appl, 38, 3 (2011)

2. C.Y. Hsu, K.T. Chen, and G.H. Tzeng, Int J Fuzzy Syst, 9, 4 (2007)

3. J. Jassbi, F. Mohamadnejad, and H. Nasrollahzadeh, Expert Syst Appl, 38, 5 (2011)

4. J.L. Yang and G.H. Tzeng, Expert Syst Appl, 38, 3 (2011)

5. M.S. Kuo, Expert Syst Appl, 38 (2011)

6. Q. Zhou, W. Huang, and Y. Zhang, Safety Sci, 49, 2 (2011)

7. S. Opricovic and G. H. Tzeng, Int J Uncertain Fuzz, 11, 5 (2003)

8. T.F. Golob and A.C. Regan, Transport Res C- Emer, 9, 2 (2001)

9. W.H. Tsai and W.C. Chou, Expert Syst Appl, 36, 2 (2009)

10. W.S. Lee, A.Y. Huang, Y.Y. Chang, and C.M. Cheng, Expert Syst Appl, 38 (2011)

11. W.W. Wu and Y.T. Lee, Expert Syst Appl, 32, 2 (2007)

12. W.W. Wu, Expert Syst Appl, 35 (2008) 